\title{
Time perception and age
}

\author{
Percepção do tempo e idade \\ Vanessa Fernanda Moreira Ferreira, Gabriel Pina Paiva, Natália Prando, Carla Renata Graça, \\ João Aris Kouyoumdjian
}

\begin{abstract}
Our internal clock system is predominantly dopaminergic, but memory is predominantly cholinergic. Here, we examined the common sensibility encapsulated in the statement: "time goes faster as we get older". Objective: To measure a 2 min time interval, counted mentally in subjects of different age groups. Method: 233 healthy subjects (129 women) were divided into three age groups: G1, 15-29 years; G2, 30-49 years; and G3, 50-89 years. Subjects were asked to close their eyes and mentally count the passing of $120 \mathrm{~s}$. Results: The elapsed times were: G1, mean $=114.9 \pm 35 \mathrm{~s} ; \mathrm{G} 2$, mean $=96.0 \pm 34.3 \mathrm{~s} ; \mathrm{G} 3$, mean $=86.6 \pm 34.9 \mathrm{~s}$. The ANOVA-Bonferroni multiple comparison test showed that $G 3$ and $G 1$ results were significantly different $(P<0.001)$. Conclusion: Mental calculations of $120 \mathrm{~s}$ were shortened by an average of $24.6 \%$ (28.3 s) in individuals over age 50 years compared to individuals under age 30 years.
\end{abstract}

Keywords: time perception; age; timing; aging.

\section{RESUMO}

Nosso sistema de relógio interno é predominantemente dopaminérgico, mas a memória é predominantemente colinérgica. Neste estudo, examinamos a assertiva comum que "o tempo passa mais rápido para pessoas mais velhas". Objetivo: Medir o intervalo de tempo 2 min contados mentalmente em pessoas de diferentes faixas etárias. Método: 233 pessoas saudáveis (129 mulheres) foram divididos em três grupos: G1, 15-29 anos; G2, 30-49 anos; e G3, 50-89 anos. Foi solicitado que contassem mentalmente, com os olhos fechados, a passagem de 120 s. Resultados: Os tempos aferidos foram: G1, média = 114,9 \pm 35 s; G2, média = 96,0 $\pm 34,3$ s; G3, média = 86,6 4 34,9 s. A comparação entre os tempos de G3 e G1 (teste de comparação múltipla ANOVA-Bonferroni) foi muito significante ( $P<0,001)$. Conclusão: Cálculo mental de 120 s foi encurtado em média 24,6\% (28,3 s) em pessoas maiores que 50 anos quando comparado com pessoas menores que 30 anos.

Palavras-chave: percepção de tempo; idade; tempo; envelhecimento.

The human body does not have time sensing receptors; thus, there is no association between time and sensory-specific systems ${ }^{1}$. We have receptors under the skin for sensing touch, temperature, pain, pressure, and vibration. In addition, we have proprioceptors in muscles and tendons, which continuously generate action potentials to the central nervous system with information about the length and tension of muscles; this signaling allows us to make accurate movements. We also have highly specialized sensory systems, such as vision, hearing, olfaction, and gustation, which provide us with environmental information. Although we are not endowed with time receptors ${ }^{2,3}$, our brains have an inherent ability to process time through the functions of neuronal mechanisms and neurotransmitters.

We carry watches to know the hour precisely, but we do not need similar devices to determine whether it is cold or whether a sound is loud or soft. Similarly, our perception of time refers to subjective experience and depends on an internal clock. The subjective duration of events may be based on brain units that accumulate over time ${ }^{4,5,6,7}$. It is commonly said that "time passes faster" in older people ${ }^{8}$, which may be due to central dopamine-related mechanisms and memory ${ }^{9,10}$. This study aimed to estimate the passage of time in different age groups, to test the truth of this saying.

\section{METHOD}

This study included 233 healthy subjects, including 129 women. Three groups were formed according to age: Group 1 comprised 86 subjects, aged 15-29 years; the mean age was 22.4 years. Group 2 comprised 76 subjects, aged 30-49 years; the mean age was 38.9 years. Group 3 comprised 71 subjects, aged 50-89 years; the mean age was 59.7 years. Each of the participants was asked to count mentally with eyes closed the passage of $120 \mathrm{~s}(2 \mathrm{~min})$. When the participant

Faculdade de Medicina de São José do Rio Preto (FAMERP), Departamento de Ciências Neurológicas, São José do Rio Preto SP, Brazil.

Correspondence: João Aris Kouyoumdjian; Rua Coronel Spínola de Castro, 4300; 15015-500 São José do Rio Preto SP, Brasil; E-mail: jaris@terra.com.br

Conflict of interest: There is no conflict to interest to declare.

Received 07 October 2015; Accepted 29 December 2015. 
finished, one of the examiners marked down the actual elapsed time; thus, the mental time or "brain clock" was compared with the actual time interval according to the clock. For instance, if a subject count mentally 120 s ("brain clock") in just $90 \mathrm{~s}$ ("real clock"), he/she time perception is faster. For them, time goes faster. All subjects were conscious, fully oriented with no past history of neurological disease or memory complaints. In all cases, the examiners checked with them before the test if they had an understanding of time and the meaning of 1 second. The use of drugs, in general, was not a criterion for exclusion, because it is difficult to find older individuals that do not take medications. The use of anxiolytics, in small doses, and antidepressants, was accepted, but these individuals represented less than $10 \%$ of the study cohort. Individuals were also stratified by education level.

All data were entered in a worksheet and tabulated for the 3 age groups. Statistical analyses for multiple comparisons between groups were performed with the ANOVABonferroni test. The study was approved by the local ethics committee, and all subjects signed informed consent forms.

\section{RESULTS}

Within each group, the times elapsed during mental counting followed a normal (Gaussian) distribution. Mean elapsed times were: G1, $114.9 \pm 35$ s; G2, $96.0 \pm 34.3$ s; and G3, $86.6 \pm 34.9$ s. Multiple comparisons with the ANOVA-Bonferroni test showed that G3 times were significantly different from G1 times $(\mathrm{p}<0.001$; Figure).

\section{DISCUSSION}

Our data clearly confirmed the assertion that "time passes faster for older individuals". We found that the mental perception of the passage of $120 \mathrm{~s}$ among older people (> 50 years) was significantly reduced compared to the perception in younger people (< 30 years). The difference between these age groups was $24.6 \%$ (28.3 s) for mean times and $28.4 \%$ (32.5 s) for median times. These data indicated that the perception of time passage was accelerated in aging. This phenomenon may be related to two mechanisms: (1) a lack of new experiences ${ }^{11}$ and (2) a reduction in dopamine neurotransmission, ${ }^{9,10,12}$.

\section{New experiences}

The time it takes to learn something new ("the first time") is always subjectively prolonged, such as a first sexual relationship, a first job, a first trip without parents, or the first experience of living away from home ${ }^{13}$. Novelty has a strong impact on memory. Generally, we can vividly remember the beginning of each new experience that occurred between ages 15 and 25 years. This may partly explain why a random day can seem longer for a child than an adult ${ }^{14}$. Most external and internal experiences are new to children, and most experiences are repetitive for adults.

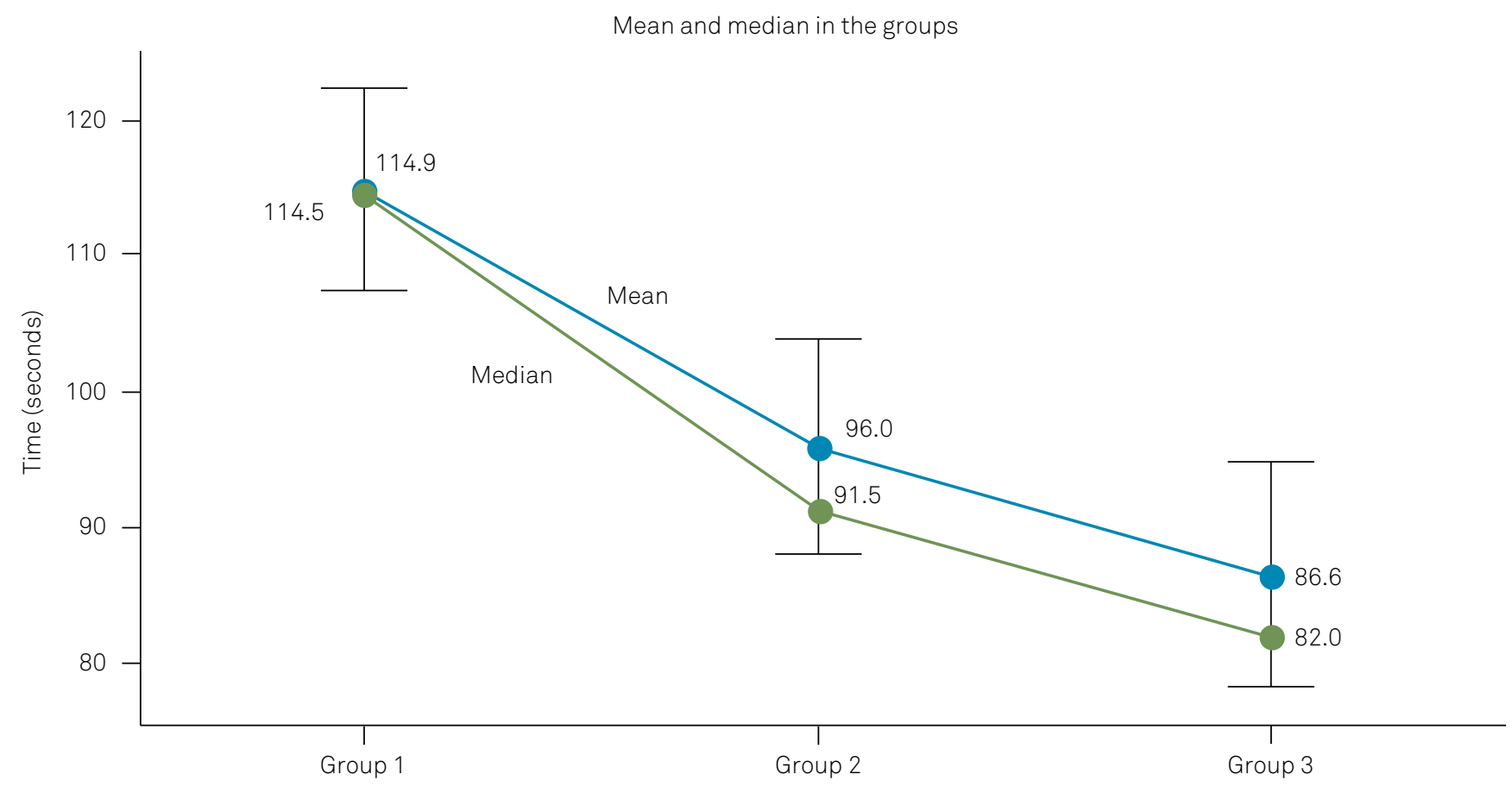

Figure. Mental perceptions of the passage of 120 s in different age groups. Group 1: aged 15-29 years; Group 2: aged 30-49 years; Group 3: aged 50-89 years. Values indicate the mean (upper line) and median (lower line) of each group; error bars indicate standard deviations. 


\section{Dopamine and neuropathways}

The ability of our internal clock to estimate the passage of time depends on both attention and memory ${ }^{9}$. For example, estimating the time necessary to perform a given task requires both concentration and memorization of a sequence of information. Concentration depends on the function of dopamine neurotransmission in the basal ganglia. Memory depends on acetylcholine neurotransmission in brain areas related to memory in the hippocampal-prefrontal cortex axis².

The neurotransmitter dopamine was associated with variations in time at the level of seconds and minutes ${ }^{6}$. Experimental studies have shown that rats can estimate time intervals up to $40 \mathrm{~s}$, despite the removal of their entire cerebral cortex. Those findings indicated that time estimation must be a subcortical process ${ }^{6}$.

In humans, time intervals are generally overestimated with the use of stimulants and underestimated with the use of depressants and anesthetics. Patients with Parkinson disease, schizophrenia, or attention-deficit hyperactivity disorder, which are all associated with abnormalities in brain dopamine levels, typically exhibit abnormalities in time perception $^{15,16}$. Stimulants that increase the function of dopamine in the brain have the effect of accelerating the perception of time. Conversely, antipsychotic drugs, or emotions of sadness and depression, block dopamine receptors and have the opposite effect ${ }^{17}$.

The consciousness of time develops during childhood, when we form the capacities for both attention and shortterm memory. The integration of these capacities depend on the slow maturation of the hippocampus and prefrontal cortex ${ }^{18}$. For example, when we become accustomed to a certain time period, e.g., a class of $30 \mathrm{~min}$, that time depends on memory (and the neurotransmitter, acetylcholine). Indeed, it does not take long for us to notice that a red traffic light is defective after it fails to turn green, because the memory of that time is stored ${ }^{9}$. On the other hand, when we are at a party and someone asks how long we have been there, we imagine a value in the absence of memory, and variations can be extensive (dependent on dopamine levels).

Imagined time also depends on behavioral mechanisms. The perception of time during a stressful or fearful situation seems much longer than the actual time that passes ${ }^{4,19,20}$. Terror movie scenes are imagined as lasting 2-fold, and sometimes 3 -fold longer than the actual time that passes. This was demonstrated in a classic study, where people with arachnophobia were invited to look for spiders for $45 \mathrm{~s}-$ an activity that elicited intense fear; those individuals greatly overestimated the time elapsed ${ }^{13}$. Similarly, when someone becomes angry with the lengthy service in call centers, the time is substantially overestimated, frequently by two-fold.

\section{Why does time seem to accelerate as we age?}

The apparent rapidity of time is a major cognitive illusion ${ }^{8}$. When we are reminded of school holidays, or for example, when we learn to swim or fly a kite, the memory seems endless. But that is an illusion. Adulthood does not hold the constant, never-ending discovery of new things that is inherent in childhood. Also, the higher the demand required of a cognitive task, the greater the perceived duration. Thus, repeated stimuli appear briefer than new stimuli of equal duration. As a result, it is possible that learning new things can slow the internal sense of time. Moreover, among healthy individuals, aging is typically connected to reduced interest in learning new things that require great effort; thus, a reluctance to learn may contribute to an accelerated internal sense of timing.

In conclusion, we found a significant reduction in the mental perception of the passage of $120 \mathrm{~s}$ for older people compared to younger people. The reasons for this phenomenon may be explained by differences in dopaminergic and/or cholinergic pathways or the integration between these two pathways. Future studies should investigate these possibilities.

\section{References}

1. Rao SM, Mayer AR, Harrington DL. The evolution of brain activation during temporal processing. Nat Neurosci. 2001;4(3):317-23. doi:10.1038/85191

2. Coull JT, Cheng RK, Meck WH. Neuroanatomical and neurochemical substrates of Timing. Neuropsychopharmacology. 2011;36(1):3-25. doi:10.1038/npp.2010.113

3. Wassenhove V, Wittmann M, Craig AD, Paulus MP. Psychological and neural mechanisms of subjective time dilation. Front Neurosci. 2011;5:56. doi:10.3389/fnins.2011.00056

4. Stetson C, Fiesta MP, Eagleman DM. Does time really slow down during a frightening event? PLoS One. 2007;2(12):e1295. doi:10.1371/journal.pone.0001295

5. Durstewitz D. Neural representation of interval time. Neuroreport. 2004;15(5):745-9. doi:10.1097/00001756-200404090-00001

6. Matell MS, Meck WH. Cortico-striatal circuits and interval timing: coincidence detection of oscillatory processes. Cognitive Brain Res. 2004;21(2):139-70. doi:10.1016/j.cogbrainres.2004.06.012
Karmarkar UR, Buonomano DV. Telling time in the absence of clocks: encoding time in neural network. Neuron. 2007;53(3):427-38. doi:10.1016/j.neuron.2007.01.006

8. Popova M. Why time slows down when we're afraid, speeds up as we age, and gets warped on vacation. [cited 2014 October 30]. Available from: http://www.brainpickings.org/2013/07/15/time-warpedclaudia-hammond/

9. Meck WH. Neuropharmacology of timing and time perception. Cogn Brain Res. 1996;3(3-4):227-42. doi:10.1016/0926-6410(96)00009-2

10. Dreher JC, Meyer-Lindenberg A, Kohn P, Berman KF. Age-related changes in midbrain dopaminergic regulation of the human reward system. Proc Natl Acad Sci USA. 2008;105(39):15106-11. doi:10.1073/pnas.0802127105

11. Friedman RA. Fast time and the aging mind. New York Times. 2013 Jul 20. Sunday Review.

12. Bäckman L, Nyberg L, Lindenberger U, Li SC, Farde L. The correlative triad among aging, dopamine, and cognition: current status and 
future prospects. Neurosci Biobehav Rev. 2006;30(6):791-807. doi:10.1016/j.neubiorev.2006.06.005

13. Hammond C. Time warped: unlocking the mysteries of time perception. Digital ed. Great Britain: Canongate Books; 2012

14. Adler R. Look how time flies... New Scientist. 1999 Dec 15. Conference report.

15. Levy F, Swanson JM. Timing, space and ADHD: the dopamine theory revisited. Aust N Z J Psychiatry. 2001;35(4):504-11. doi:10.1046/j.1440-1614.2001.00923.x

16. Smith A, Taylor E, Rogers JW, Newman S, Rubia K. Evidence for a pure time perception deficit in children with ADHD. J Child Psychol Psychiatry. 2002;43(4):529-42. doi:10.1111/1469-7610.00043
17. Gil S, Droit-Volet S. Time perception, depression and sadness. Behav. Processes 2009;80(2):169-76. doi:10.1016/j.beproc.2008.11.012

18. Kolb B, Mychasiuk R, Muhammad A, Li Y, Frost DO, Gibb R. Experience and the developing prefrontal cortex. Proc Natl Acad Sci USA. 2012;109 (Suppl 2):17186-93. doi:10.1073/pnas.1121251109

19. Droit-Volet S, Fayolle SL, Gil S. Emotion and time perception: effects of film-induced mood. Front Integr Neurosci. 2011;5:33. doi:10.1073/pnas.1121251109

20. Rudd M, Vohs KD, Aaker J. Awe expands people's perception of time, alters decision making, and enhances well-being. Psychol Sci. 2012;23(10):1130-6. doi:10.1177/0956797612438731 